\title{
ANALISIS KOLOM BETON DENGAN BEBAN AKSIAL MENGGUNAKAN METODE ELEMEN HINGGA
}

\author{
Arief Kusbiantoro $^{1 *}$, Sulistyowati ${ }^{2}$, danWidayat Amariansyah ${ }^{3}$ \\ 1,2,3 Program Studi D3 Teknik Sipil, Fakultas Teknik, Universitas Pandanaran \\ Email: ariefkusb@gmail.com
}

\begin{abstract}
ABSTRAK
Kolom merupakan bagian yang sangat penting dalam sebuah strukur bangunan. Berdasarkan prinisp perencanaan "Strong column weak beam", kolom sangat menentukan dalam stabilitas suatu bangunan. Pada tulisan ini dilakukan analisa teoritis menggunakan metode elemen hingga, ANSYS. Perkembangan program komputer di bidang teknik sipil semakin mempermudah dalam melakukan analisa. Salah satunya adalah ANSYS, sebuah program metode elemen yang sangat membantu dalam melakukan analisa terhadap suatu bahan sehingga bisa dianggap sebagai virtual laboratorium. ANSYS dapat digunakan untuk membantu melakukan simulasi dan menentukan dugaan awal sebelum melakukan percobaan sesungguhnya di laboratorium. Pada simulasi ini menggunakan kolom beton berbentuk silinder dengan diameter $20 \mathrm{~cm}$ dan tinggi $150 \mathrm{~cm}$. Kolom mendapat beban aksial sentris sebesar 15000 N. Pada program elemen hingga, elemen dibagi menjadi bagian2bagian yang kecil sehingga dari analisa akan diketahui hasil akhir berupa momen, gaya geser dan lendutan di tiap titik-titik sesuai dengan pembagian elemen nya ( meshing ). Lendutan terbesar 0,023583 mm di bagian atas kolom, sedangkan di dasar kolom tidak terjadi lendutan. Tegangan yang terbesar di dasar kolom bagian samping sebesar 0,52378 MPa, dan tegangan terkecil di dasar kolom bagian tengah sebesar 0,32789 Mpa.
\end{abstract}

Kata kunci : kolom, metode elemen hingga, beban aksial

\section{PENDAHULUAN}

Metode elemen hingga adalah metode umum untuk membuat perkiraan solusi terhadap batasan masalah. Metode dilakukan dengan membagi area yang diteliti menjadi jumlah tertentu dan menggunakan berbagai konsep untuk membentu perkiraan dari solusi yang meliputi kumpulan elemen dalam jumlah tertentu. Analisis struktur adalah perhitungan dari reaksi struktur yang diakibatkan beban yang timbul. Ada 3 komponen dasar dalam analisis struktur: struktur itu sendiri, pembebanan, dan reaksi. Dalam analisa struktur, struktur dan pembebanan sudah diketahui, sedangkan reaksi yang akan dicari.

Ada beberapa metode empiris dan semi empiris dalam perhitungan lendutan yang ada di beberapa peraturan. Misalnya di peraturan tersebut, ACI adalah yang paling baru dan metode yang sering dipakai untuk perhitungan lendutan. Tetapi metode ini melupakan beberapa perilaku kolom dan sifat material. Sebagai contoh, itu tidak menggambarkan keberagaman beton, beton dianggap sebagai material yang homogen dan material isotropic. Saat ini permasalahan tersebut, material yang homogen, batas kondisi yang kompleks sudah diatasi dengan permodelan yang benar di FE.
Penelitian tentang simulasi pembebanan aksial pada kolom menggunakan metode elemen hingga sudah dilakukan oleh beberapa peneliti. Untuk kedepannya bisa dilakukan penelitian simulasi lanjutan untuk kolom yang diperkuat dengan tulangan dan mendapat beban aksial yang asimetris.

Sebagian besar metode analisis untuk kolom RC berdasarkan pada keseimbangan. Sifat material penampang dianggap satu untuk meneliti perilaku yang sesungguhnya. Analisis elastis balok RC dapat dilakukan dengan konsep perubahan area, dimana baja dalam tekan dan tarik digantikan dengan luasan beton yang tertentu.

Program komputer untuk menganalisa strukur RC sedang dikembangkan diberbagai belahan dunia. Untuk menganalisa lendutan kolom akibat beban aksial, menentukan efek kekuatan dan rasio perkuatan lentur memikul kapasitas kolom dan memperluas cakupan program sehingga analisa dan perencanaan dapat dilakukan berulang untuk lebih diperhatikan dalam perubahan dalam kapasitas kolom yang disebabkan karena perubahan penampang. 


\section{LANDASAN TEORI}

Program analisa metode elemen hingga ANSYS membantu insinyur untuk menghitung beberapa tugas, membuat model struktur, menerapkan beban, mempelajari reaksi seperti tegangan, distribusi suhu. Program ANSYS mempunyai interaksi dengan pengguna yang cukup lengkap yang memberikan berbagai kemudahan untuk menggunakan fungsi, commands, dokumentasi, dan referensi material.

Analisis dengan experiment secara luas sudah dilakukan untuk mempelajari komponen dan kekuatan beton di bawah berbagai kondisi pembebanan. Metode Finite Element Analysis (FEA) juga digunakan untuk menganalisa struktur, menyediakan prediksi reaksi komponen yang akurat yang disebabkan karena berbagai kondisi pembebanan. Penggunaan FEA telah menjadi metode yang disukai untuk mempelajari perilaku beton yang lebih cepat dari metode laboratorium dan biaya yang lebih murah. Dengan penemuan alat numerik yang canggih untuk analisa spt Finite Element Method (FEM), sudah menjadi kenyataan untuk memodelkan perilaku kolom beton yang kompleks menggunakan FEM. FEA dapat juga digunakan untuk membuat model perilaku numeris untuk mengecek perhitungan, juga untuk menyediakan tambahan yang berharga bagi penyeledikan laboratorium , khususnya dalam penelitian parameter.

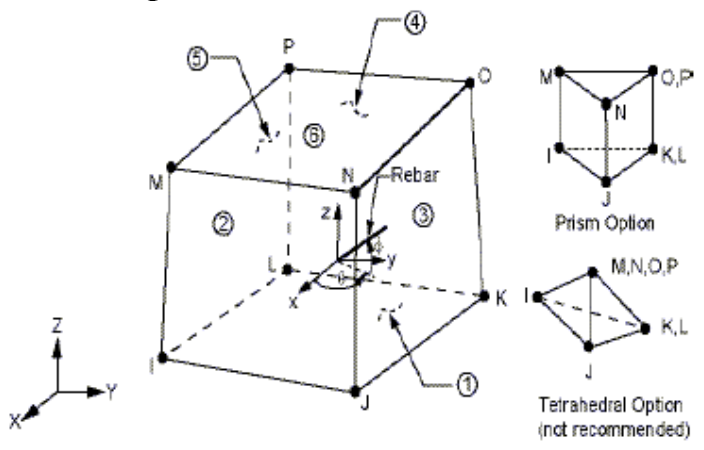

Gambar 1. Elemen Solid 65

\section{Tipe Elemen}

Untuk memodelkan beton, menggunakan elemen solid 8 titik SOLID 65. Elemen solid mempunyai 8 titik dengan tiga derajat kebebasan pada tiap titik, perpindahan titik dalam arah $x, y$, dan $\mathrm{z}$. Elemen mampu untuk deformasi plastic, retakan dalam arah 3 dimensi dan runtuh. Aspek yang sangat penting dari elemen ini adalah perlakuan sifat non linier (Thomas, 2002).

Perkuatan untuk model elemen hingga dianggap elastis sempurna dan identik dalam tarik dan tekan. Beton merupakan material dan mempunyai perilaku yang berbeda dalam tarik dan tekan. Dalam tekan, kurva tegangan regangan untuk beton masih linier sampai 30\% dari kekuatan tekan maksimum. Melewati kuat tekan maksimum, kurva menjadi daerah yang lebih landai dan secepatnya keruntuhan terjadi pada regangan ultimate. Untuk inputan data beton di ANSYS, membutuhkan modulus elastisitas beton (Ec), kuat tekan ultimate (fc), modulus keruntuhan (fr) dan posiion rasio (v). Koefisien tekan diambil 8000 psi dan rasio Poison sebesar 0.18 .

\section{Sifat Material}

Beton adalah material yang mendekati getas dan mempunyai hubungan antara tegangan regangan dan nonlinier. Sifat perilaku nonlinier melengkapi bentuk dan penambahan retakan mikro selama pembebanan. Kuat tarik beton sekitar 8-15\% dari kuat tekan. Gambar 4 menunjukkan kurva tegangan regangan untuk berat normal beton. Dalam tekanan, kurva tegangan regangan untuk beton linier sampai mendekati 30\% dari kuat tekan maksimum. Di atas titik ini tegangan bertambah sedikit sampai mencapai kuat tekan maksimum ocu', kurva menurun sampai daerah soft dan secepatnya terjadi kegagalan kehancuran pada regangan puncak $\varepsilon c u$. Dalam tarik, kurva tegangan regangan untuk beton kira-kira linier sampai kuat tekan maksimum. Setelah titik ini, beton mengalami retakan dan kuat tekan menurun sampai mencapai nol.

Berbagai model matematika tersedia untuk memperkirakan perilaku non linier. Dalam tulisan ini, hubungan tegangan regangan beban tekan uniaxial untuk beton didapatkan menggunakan model elastis Hognestead yg dimodifikasi. Persamaan berikut digunakan untuk menghitung kurva tegangan regangan multi linier untuk beton.

$$
\begin{aligned}
& \mathrm{Ec}=5000 \sqrt{\mathrm{fck}} \\
& \mathrm{f}=\frac{E c \varepsilon}{1+\left(\frac{\varepsilon}{\varepsilon 0}\right)^{2}} \\
& \varepsilon_{0}=\frac{2 f c k}{E c} \\
& \mathrm{Ec}=\frac{f}{\varepsilon} \\
& \text { Dimana : } \\
& \mathrm{F}=\text { tegangan pada setiap regangan } \varepsilon, \mathrm{Mpa}
\end{aligned}
$$


$\varepsilon=$ regangan pada tegangan $\mathrm{f}$

$\varepsilon_{0}=$ regangan pada kuat tekan maksimum fck

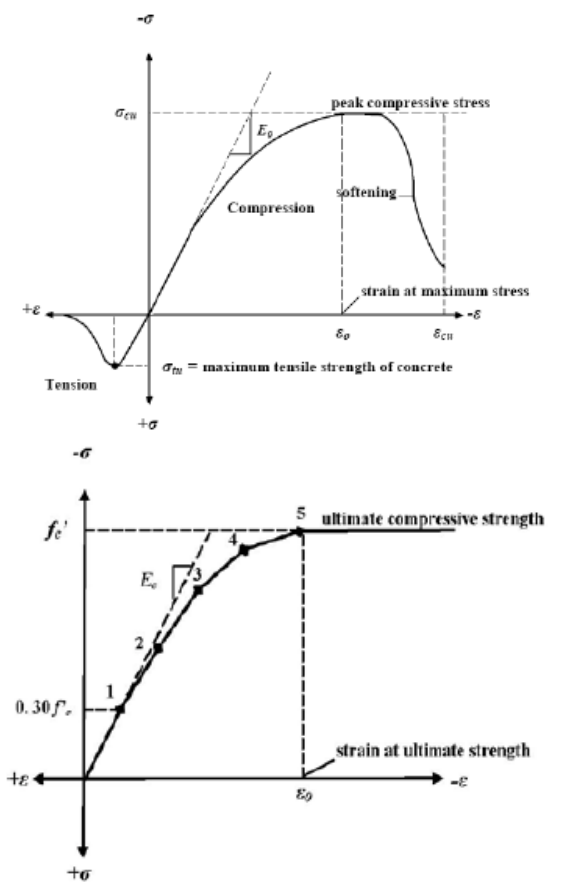

Gambar 2. Tegangan Regangan Beton

Model bisa digunakan untuk memprediksi kegagalan pada material beton. Bentuk kegagalan retakan dan keruntuhan dicatat. Dua input parameter kekuatan seperti kuat tarik uniaxial ultimat dan kuat tekan dibutuhkan untuk menentukan kegagalan permukaan beton. Akibatnya, kriteria kegagalan beton disebabkan bentuk tegangan multiaxial dapat dihitung.

Dalam elemen beton, retakan terjadi jika tegangan utama tarik dalam beberapa arah terletak di luar bidang runtuh. Setelah retak, modulus elastis elemen beton dibuat nol dalam arah paralel terhadap arah tegangan tarik utama. Kehancuran terjadi jika semua tegangan utama tertekan dan terletak di luar bidang keruntuhan : berurutan, modulus elastisitas bernilai nol di semua arah.

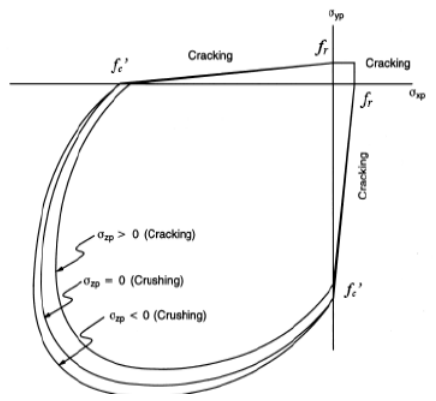

Gambar 3. Kegagalan permukaan beton

\section{Pembagian Elemen}

FEM adalah garis-garis elemen yang digunakan untuk membentuk objek yang akan diteliti. Aspek penting dari model FE yang mempengaruhi analisa adalah aspek rasio dari bidang elemen. Aspek rasio menggambarkan bentuk elemen dalam secara keseluruhan. Optimal aspek rasio pada berbagai lokasi dalam grid tergantung secara luas dalam tingkat perubahan displacement dalam arah yang berbeda.

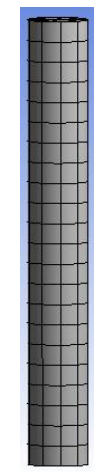

Gambar 4. Pembagian model

\section{HASIL DAN PEMBAHASAN \\ Data Masukan Model}

Tabel 1. Data Masukan model

\begin{tabular}{|c|cc|}
\hline \multicolumn{3}{|c|}{ Ukuran } \\
\hline Arah X & 200 & $\mathrm{~mm}$ \\
\hline Arah Y & 1500 & $\mathrm{~mm}$ \\
\hline Arah Z & 200 & $\mathrm{~mm}$ \\
\hline Volume & $4,71 \mathrm{E}+07$ & $\mathrm{~mm}^{3}$ \\
\hline Massa & 108,38 & $\mathrm{~kg}$ \\
\hline Titik & 1477 & \\
\hline
\end{tabular}

\section{Tahap Pembebanan}

Batang tekan adalah elemen struktural yang hanya menerima gaya tekan aksial, dimana gaya bekerja pada sumbu longitudinal melalui sentroid dari penampang, dan gaya tekan bisa dirumuskan menjadi $\mathrm{f}=\mathrm{P} / \mathrm{A}$, dimana $\mathrm{f}$ dianggap sama bekerja pada seluruh penampang. (Segui, 2007). 


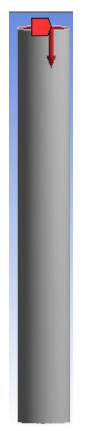

Gambar 5. Pembebanan

\section{Total Deformasi}

Akibat pembebanan yang ada, benda uji akan mengalami deformasi. Dari uji simulasi dengan menggunakan program ANSYS, ada 9 fase dalam proses deformasi mulai dari pembebanan sampai dengan mencapai kondisi deformasi final, sebesar 0,0238 $\mathrm{mm}$ di bagian atas kolom.
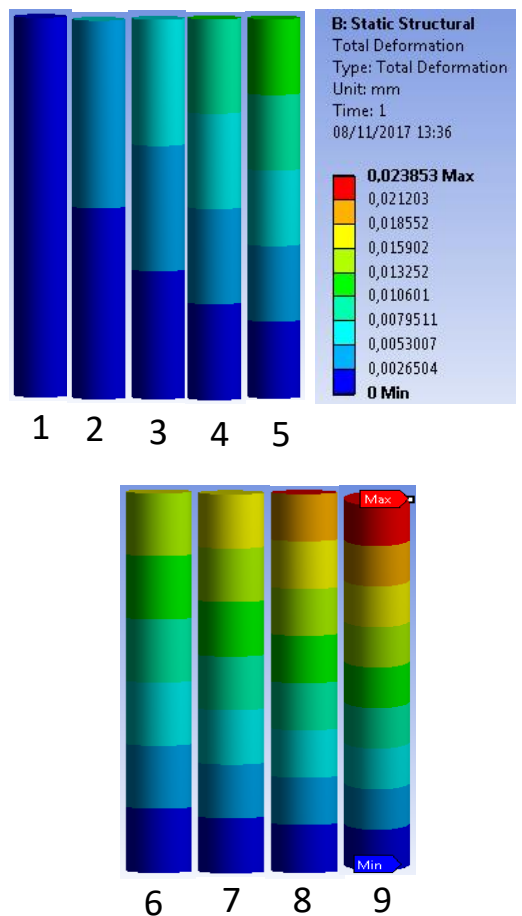

Gambar 6. Total Deformasi

Tabel 2. Deformasi fase 1

\begin{tabular}{|l|c|c|}
\hline \multicolumn{1}{|c|}{ Warna } & \multicolumn{2}{c|}{ Deformasi $(\mathrm{mm})$} \\
\hline Merah & 0,0212 & 0,0238 \\
\hline Coklat & 0,0186 & 0,0212 \\
\hline Kuning muda & 0,0016 & 0,0186 \\
\hline Kuning hijau & 0,0133 & 0,0016 \\
\hline Hijau muda & 0,0106 & 0,0133 \\
\hline
\end{tabular}

\begin{tabular}{|l|l|l|} 
Hijau biru & 0,0080 & 0,0106 \\
\hline Biru muda & 0,0053 & 0,0080 \\
\hline Biru muda & 0,0027 & 0,0053 \\
\hline Biru tua & 0,0000 & 0,0027 \\
\hline
\end{tabular}

Pada fase pertama, saat awal pembebanan deformasi masih belum begitu terlihat yang ditunjukkan dengan warna biru tua dengan besaran deformasi berkisar antara $0 \mathrm{~mm}$ sampai dengan $0,0027 \mathrm{~mm}$.

Tabel 3. Deformasi Fase 2

\begin{tabular}{|l|l|l|}
\hline Jarak $(\mathrm{m})$ & \multicolumn{2}{|c|}{ Kisaran Deformasi } \\
\hline $0-0,75$ & 0,0000 & 0,0027 \\
\hline $0,75-1,5$ & 0,0027 & 0,0053 \\
\hline
\end{tabular}

Tabel 4. Deformasi Fase 3

\begin{tabular}{|l|l|l|}
\hline Jarak $(\mathrm{m})$ & \multicolumn{2}{|c|}{ Kisaran Deformasi } \\
\hline $0-0,5$ & 0,0000 & 0,0027 \\
\hline $0,5-1$ & 0,0027 & 0,0053 \\
\hline $1-1,5$ & 0,0053 & 0,0080 \\
\hline
\end{tabular}

Tabel 5. Deformasi Fase 4

\begin{tabular}{|l|c|c|}
\hline Jarak $(\mathrm{m})$ & \multicolumn{2}{|c|}{ Kisaran Deformasi } \\
\hline $0-0,375$ & 0,0000 & 0,0027 \\
\hline $0,375-0,75$ & 0,0027 & 0,0053 \\
\hline $0,75-1,125$ & 0,0053 & 0,0080 \\
\hline $1,125-1,5$ & 0,0080 & 0,0106 \\
\hline
\end{tabular}

Tabel 6. Deformasi Fase 5

\begin{tabular}{|l|c|c|}
\hline Jarak $(\mathrm{m})$ & \multicolumn{2}{|c|}{ Kisaran Deformasi } \\
\hline $0-0,3$ & 0,0000 & 0,0027 \\
\hline $0,3-0,6$ & 0,0027 & 0,0053 \\
\hline $0,6-0,9$ & 0,0053 & 0,0080 \\
\hline $0,9-1,2$ & 0,0080 & 0,0106 \\
\hline $1,2-1,5$ & 0,0106 & 0,0133 \\
\hline
\end{tabular}

Tabel 7. Deformasi Fase 6

\begin{tabular}{|l|c|c|}
\hline Jarak $(\mathrm{m})$ & \multicolumn{2}{|c|}{ Kisaran Deformasi } \\
\hline $0-0,25$ & 0,0000 & 0,0027 \\
\hline $0,25-0,5$ & 0,0027 & 0,0053 \\
\hline $0,5-0,75$ & 0,0053 & 0,0080 \\
\hline $0,75-1$ & 0,0080 & 0,0106 \\
\hline $1-1,25$ & 0,0106 & 0,0133 \\
\hline $1,25-1,5$ & 0,0133 & 0,0016 \\
\hline
\end{tabular}


Tabel 8. Deformasi Fase 7

\begin{tabular}{|l|c|c|}
\hline Jarak $(\mathrm{m})$ & \multicolumn{2}{|c|}{ Kisaran Deformasi } \\
\hline $0-0,21$ & 0,0000 & 0,0027 \\
\hline $0,21-0,42$ & 0,0027 & 0,0053 \\
\hline $0,42-0,63$ & 0,0053 & 0,0080 \\
\hline $0,63-0,84$ & 0,0080 & 0,0106 \\
\hline $0,84-1,05$ & 0,0106 & 0,0133 \\
\hline $1,05-1,26$ & 0,0133 & 0,0016 \\
\hline $1,26-1,5$ & 0,0016 & 0,0186 \\
\hline
\end{tabular}

Tabel 9. Deformasi Fase 8

\begin{tabular}{|l|c|c|}
\hline Jarak $(\mathrm{m})$ & \multicolumn{2}{|c|}{ Kisaran Deformasi } \\
\hline $0-0,19$ & 0,0000 & 0,0027 \\
\hline $0,19-0,38$ & 0,0027 & 0,0053 \\
\hline $0,38-0,56$ & 0,0053 & 0,0080 \\
\hline $0,56-0,75$ & 0,0080 & 0,0106 \\
\hline $0,75-0,94$ & 0,0106 & 0,0133 \\
\hline $0,94-1,13$ & 0,0133 & 0,0016 \\
\hline $1,13-1,31$ & 0,0016 & 0,0186 \\
\hline $1,31-1,50$ & 0,0186 & 0,0212 \\
\hline
\end{tabular}

Tabel 10. Deformasi Fase 9

\begin{tabular}{|l|l|l|}
\hline Jarak $(\mathrm{m})$ & \multicolumn{2}{|c|}{ Kisaran Deformasi } \\
\hline $0-0,17$ & 0,0000 & 0,0027 \\
\hline $0,17-0,34$ & 0,0027 & 0,0053 \\
\hline $0,34-0,51$ & 0,0053 & 0,0080 \\
\hline $0,51-0,68$ & 0,0080 & 0,0106 \\
\hline $0,68-0,85$ & 0,0106 & 0,0133 \\
\hline $0,85-1,01$ & 0,0133 & 0,0016 \\
\hline $1,01-1,17$ & 0,0016 & 0,0186 \\
\hline $1,17-1,33$ & 0,0186 & 0,0212 \\
\hline $1,33-1,5$ & 0,0212 & 0,0238 \\
\hline
\end{tabular}

Pada kondisi terakhir deformasi kolom seperti terlihat pada gambar, kolom terbagi menjadi 9 bagian warna yang berbeda. Warna tersebut menunjukkan besarnya deformasi tiap bagian dengan warna yang berbeda

\section{EQUIVALENT STRESS}

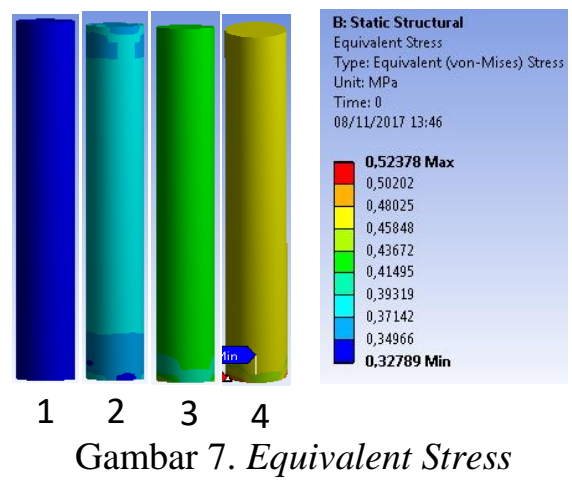

Tabel 11. Equivalent Stress

\begin{tabular}{|l|c|c|}
\hline \multicolumn{1}{|c|}{ Warna } & \multicolumn{2}{c|}{ Equivalent Stress ( Mpa ) } \\
\hline Merah & 0,502 & 0,523 \\
\hline Orange & 0,48 & 0,502 \\
\hline Kuning & 0,458 & 0,48 \\
\hline Hijau Muda & 0,436 & 0,458 \\
\hline Hijau & 0,414 & 0,436 \\
\hline Biru Muda & 0,393 & 0,414 \\
\hline Biru Muda & 0,371 & 0,393 \\
\hline Biru & 0,349 & 0,371 \\
\hline Biru Tua & 0,327 & 0,349 \\
\hline
\end{tabular}

Pada equivalent stress melewati 4 tahapan sebelum mencapat kondisi akhir. Pada fase pertama, semua bagian kolom masih berwarna biru tua dengan nilai tegangan berkisar antara 0,327 Mpa sampai 0,349 Mpa. Pada fase kedua, ujung atas dan bawah kolom berwarna biru muda dengan nilai tegangan berkisar antara 0,371 Mpa sampai 0,393 Mpa, sedangkan bagian tengah kolom berwarna biru muda dengan tegangan berkisar antara 0,393 Mpa sampai 0,414 Mpa.

Pada fase ketiga, ujung bawah kolom berwarna biru muda dengan besaran tegangan berkisar antara 0,393 Mpa sampai 0,414 Mpa, sedangkan bagian tengah sampai atas berwarna hijau dengan besaran tegangan berkisar antara 0,414 Mpa sampai 0,436 Mpa.

Pada fase terakhir, ujung bawah berwarna hijau muda dengan tegangan berkisar antara 0,436 Mpa sampai 0,458 Mpa, sedangkan bagian tengah sampai atas berwarna kuning dengan tegangan berkisar antara 0,458 sampai 0,48 . 


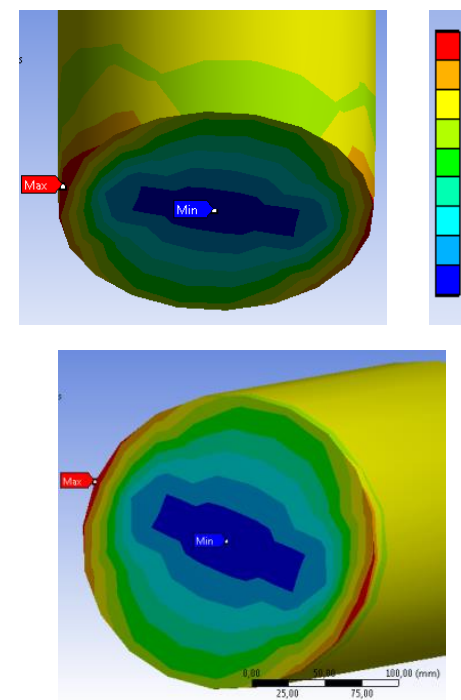

Gambar 8. Equivalent Stress

Pada penampang melintang terlihat bahwa tegangan terbesar terletak di sisi luar yang ditunjukkan sebagai warna merah dengan besar tegangan berkisar antara 0,502 Mpa sampai 0,523 Mpa. Sedangkan tegangan terkecil berada di tengah penampang yang ditunjukkan dengan warna biru tua dengan besar tegangan berkisar antara 0,327 Mpa sampai 0,349 Mpa.

\section{Directional Deformation}

Pada directional deformation dapat dilihat bahwa pada dua sisi yang berbeda mengalami arah deformasi yang berbeda. Hal tersebut dapat dilihat gambar berikut.

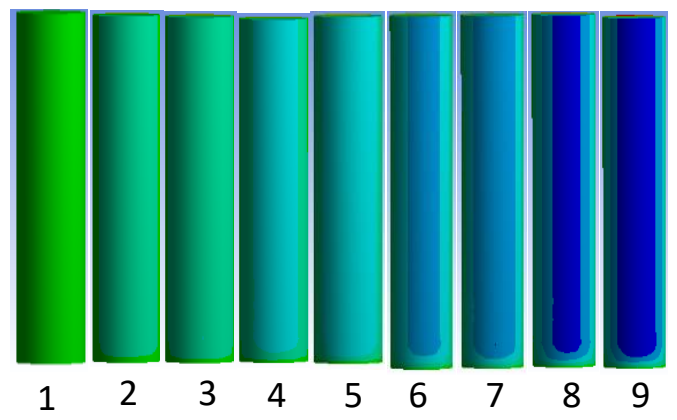

Gambar 9. Directional Deformation

Pada satu sisi terjadi perubahan warna yang menunjukkan arah deformasi sesuai dengan tabel 12. Di sisi lain menunjukkan perubahan deformasi dengan besaran yang sama tetapi dengan arah yang berbeda, dapat dilihat pada tabel 12 .

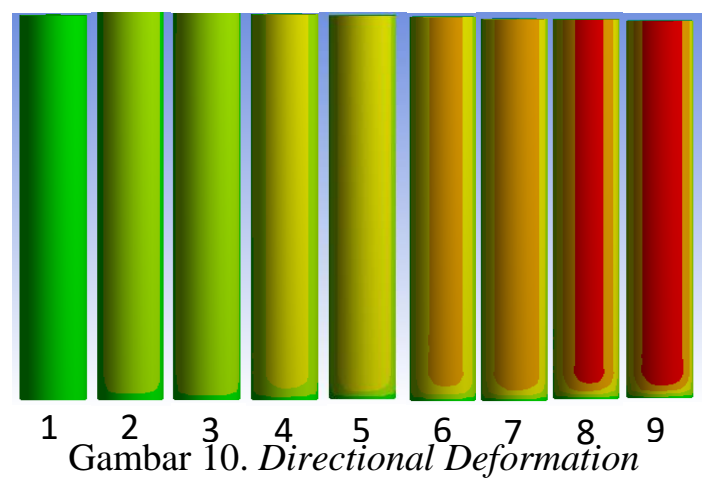

Dalam tabel 12 terlihat bahwa untuk besaran deformasi sama, hanya berbeda tanda positif (+) dan negatif (-) menunjukkan arah deformasi.

Tabel 12. Arah Deformasi

\begin{tabular}{|l|c|c|}
\hline \multicolumn{1}{|c|}{ Warna } & \multicolumn{2}{c|}{ Kisaran Arah Deformation } \\
\hline Merah & $2,93 \mathrm{E}-04$ & $2,28 \mathrm{E}-04$ \\
\hline Orange & $2,28 \mathrm{E}-04$ & $1,63 \mathrm{E}-04$ \\
\hline Kuning & $1,63 \mathrm{E}-04$ & $9,76 \mathrm{E}-05$ \\
\hline Hijau kuning & $9,76 \mathrm{E}-05$ & $3,25 \mathrm{E}-05$ \\
\hline Hijau & $3,25 \mathrm{E}-05$ & $-3,25 \mathrm{E}-05$ \\
\hline Hijau Biru & $-3,25 \mathrm{E}-05$ & $-9,75 \mathrm{E}-05$ \\
\hline Biru Muda & $-9,75 \mathrm{E}-05$ & $-1,63 \mathrm{E}-04$ \\
\hline Biru & $-1,63 \mathrm{E}-04$ & $-2,28 \mathrm{E}-04$ \\
\hline Biru Tua & $-2,28 \mathrm{E}-04$ & $-2,93 \mathrm{E}-04$ \\
\hline
\end{tabular}

Dari tampak atas atau pada potongan melintang dapat dilihat lebih jelas tentang arah deformasi seperti pada gambar di bawah.

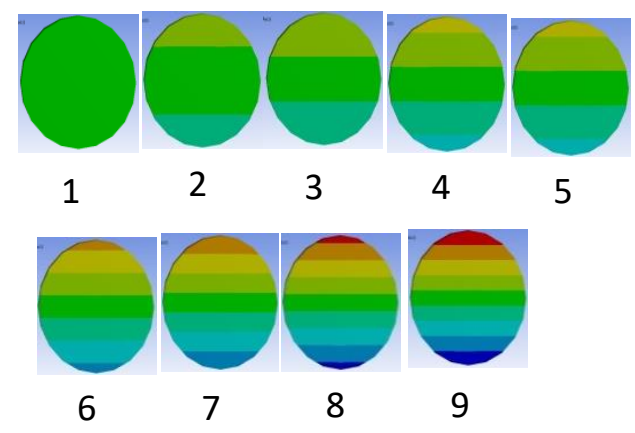

Gambar 11. Directional Deformation 
Tabel 12. Directional Fase 1

\begin{tabular}{|c|c|c|}
\hline Jarak & \multicolumn{2}{|c|}{ Kisaran Deformasi } \\
\hline $0-20$ & $-3,25 \mathrm{E}-05$ & $-3,25 \mathrm{E}-05$ \\
\hline
\end{tabular}

Tabel 13. Directional Fase 2

\begin{tabular}{|c|c|c|}
\hline Jarak & \multicolumn{2}{|c|}{ Kisaran Deformasi } \\
\hline $0-5$ & $-3,25 \mathrm{E}-05$ & \multicolumn{1}{c|}{$-3,25 \mathrm{E}-05$} \\
\hline $5-15$ & $-3,25 \mathrm{E}-05$ & $3,25 \mathrm{E}+05$ \\
\hline $15-20$ & $3,25 \mathrm{E}-05$ & $9,76 \mathrm{E}-05$ \\
\hline
\end{tabular}

Tabel 14. Directional Fase 3

\begin{tabular}{|c|c|r|}
\hline Jarak & \multicolumn{2}{|c|}{ Kisaran Deformasi } \\
\hline $0-6,7$ & $-3,25 \mathrm{E}-05$ & $-3,25 \mathrm{E}-05$ \\
\hline $6,7-13,4$ & $-3,25 \mathrm{E}-05$ & $3,25 \mathrm{E}+05$ \\
\hline $13,4-20$ & $3,25 \mathrm{E}-05$ & $9,76 \mathrm{E}-05$ \\
\hline
\end{tabular}

Tabel 15. Directional Fase 4

\begin{tabular}{|c|c|c|}
\hline Jarak & \multicolumn{2}{|c|}{ Kisaran Deformasi } \\
\hline $0-6,7$ & $-3,25 \mathrm{E}-05$ & \multicolumn{1}{c|}{$-3,25 \mathrm{E}-05$} \\
\hline $6,7-13,4$ & $-3,25 \mathrm{E}-05$ & $3,25 \mathrm{E}+05$ \\
\hline $13,4-20$ & $3,25 \mathrm{E}-05$ & $9,76 \mathrm{E}-05$ \\
\hline
\end{tabular}

Tabel 16. Directional Fase 5

\begin{tabular}{|c|r|r|}
\hline Jarak & \multicolumn{2}{|c|}{ Kisaran Deformasi } \\
\hline $0-2,5$ & $-1,62 \mathrm{E}-04$ & $-9,75 \mathrm{E}-05$ \\
\hline $2,5-7,5$ & $-9,75 \mathrm{E}-05$ & $-3,25 \mathrm{E}-05$ \\
\hline $7,5-12,5$ & $-3,25 \mathrm{E}-05$ & $3,25 \mathrm{E}-05$ \\
\hline $12,5-17,5$ & $3,25 \mathrm{E}-05$ & $9,75 \mathrm{E}-05$ \\
\hline $17,5-20$ & $9,75 \mathrm{E}-05$ & $1,62 \mathrm{E}-04$ \\
\hline
\end{tabular}

Tabel 17. Directional Fase 6

\begin{tabular}{|c|r|r|}
\hline Jarak & \multicolumn{2}{|c|}{ Kisaran Deformasi } \\
\hline $0-1,7$ & $-2,27 \mathrm{E}-04$ & $-1,62 \mathrm{E}-04$ \\
\hline $1,7-4,9$ & $-1,62 \mathrm{E}-04$ & $-9,75 \mathrm{E}-05$ \\
\hline $4,9-8,2$ & $-9,75 \mathrm{E}-05$ & $-3,25 \mathrm{E}-05$ \\
\hline $8,2-11,6$ & $-3,25 \mathrm{E}-05$ & $3,25 \mathrm{E}-05$ \\
\hline $11,6-14,9$ & $3,25 \mathrm{E}-05$ & $9,75 \mathrm{E}-05$ \\
\hline $14,9-18,3$ & $9,75 \mathrm{E}-05$ & $1,62 \mathrm{E}-04$ \\
\hline $18,3-20$ & $1,62 \mathrm{E}-04$ & $2,27 \mathrm{E}-04$ \\
\hline
\end{tabular}

Tabel 18. Directional Fase 7

\begin{tabular}{|c|c|c|}
\hline Jarak & \multicolumn{2}{|c|}{ Kisaran Deformasi } \\
\hline $0-2,85$ & $-2,27 \mathrm{E}-04$ & $-1,62 \mathrm{E}-04$ \\
\hline $2,85-5,7$ & $-1,62 \mathrm{E}-04$ & $-9,75 \mathrm{E}-05$ \\
\hline
\end{tabular}

\begin{tabular}{|c|r|r|}
$5,7-8,55$ & $-9,75 \mathrm{E}-05$ & $-3,25 \mathrm{E}-05$ \\
\hline $8,55-11,4$ & $-3,25 \mathrm{E}-05$ & $3,25 \mathrm{E}-05$ \\
\hline $11,4-14,25$ & $3,25 \mathrm{E}-05$ & $9,75 \mathrm{E}-05$ \\
\hline $14,25-17,1$ & $9,75 \mathrm{E}-05$ & $1,62 \mathrm{E}-04$ \\
\hline $17,1-20$ & $1,62 \mathrm{E}-04$ & $2,27 \mathrm{E}-04$ \\
\hline
\end{tabular}

Tabel 19. Directional Fase 8

\begin{tabular}{|c|c|c|}
\hline Jarak & \multicolumn{2}{|c|}{ Kisaran Deformasi } \\
\hline $0-1,25$ & $-2,92 \mathrm{E}-04$ & $2,27 \mathrm{E}-04$ \\
\hline $1,25-3,75$ & $-2,27 \mathrm{E}-04$ & $-1,62 \mathrm{E}-04$ \\
\hline $3,75-6,25$ & $-1,62 \mathrm{E}-04$ & $-9,75 \mathrm{E}-05$ \\
\hline $6,25-8,75$ & $-9,75 \mathrm{E}-05$ & $-3,25 \mathrm{E}-05$ \\
\hline $8,75-11,25$ & $-3,25 \mathrm{E}-05$ & $3,25 \mathrm{E}-05$ \\
\hline $11,25-13,75$ & $3,25 \mathrm{E}-05$ & $9,75 \mathrm{E}-05$ \\
\hline $13,75-16,25$ & $9,75 \mathrm{E}-05$ & $1,62 \mathrm{E}-04$ \\
\hline $16,25-18,75$ & $1,62 \mathrm{E}-04$ & $2,27 \mathrm{E}-04$ \\
\hline $18,75-20$ & $2,27 \mathrm{E}-04$ & $2,29 \mathrm{E}-04$ \\
\hline
\end{tabular}

Tabel 20. Directional Fase 9

\begin{tabular}{|c|c|c|}
\hline Jarak & \multicolumn{2}{|c|}{ Kisaran Deformasi } \\
\hline $0-2,22$ & $-2,92 \mathrm{E}-04$ & $2,27 \mathrm{E}-04$ \\
\hline $2,22-4,44$ & $-2,27 \mathrm{E}-04$ & $-1,62 \mathrm{E}-04$ \\
\hline $4,44-6,66$ & $-1,62 \mathrm{E}-04$ & $-9,75 \mathrm{E}-05$ \\
\hline $6,66-8,88$ & $-9,75 \mathrm{E}-05$ & $-3,25 \mathrm{E}-05$ \\
\hline $8,88-11,1$ & $-3,25 \mathrm{E}-05$ & $3,25 \mathrm{E}-05$ \\
\hline $11,1-13,32$ & $3,25 \mathrm{E}-05$ & $9,75 \mathrm{E}-05$ \\
\hline $13,32-15,54$ & $9,75 \mathrm{E}-05$ & $1,62 \mathrm{E}-04$ \\
\hline $15,54-17,76$ & $1,62 \mathrm{E}-04$ & $2,27 \mathrm{E}-04$ \\
\hline $17,76-20$ & $2,27 \mathrm{E}-04$ & $2,29 \mathrm{E}-04$ \\
\hline
\end{tabular}

\section{STRAIN ENERGY}

Dalam strain energy mengalami 8 fase sampai mencapai kondisi final.

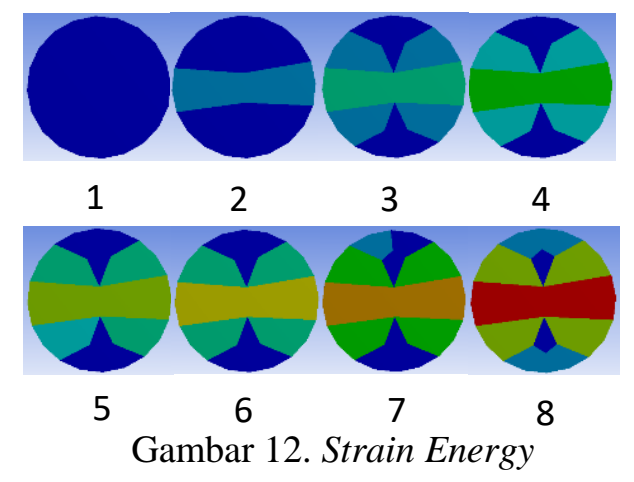


Besaran strain energy tiap-tiap fase dapat dilihat pada tabel 21 berikut.

Tabel 21. Strain Energy

\begin{tabular}{|l|c|c|}
\hline \multicolumn{1}{|c|}{ Warna } & \multicolumn{2}{c|}{ Kisaran Strain Energy } \\
\hline Biru tua & 0,206 & 0,332 \\
\hline Biru muda & 0,332 & 0,459 \\
\hline Biru muda & 0,459 & 0,585 \\
\hline Biru muda hijau & 0,585 & 0,712 \\
\hline Hijau muda & 0,712 & 0,839 \\
\hline Hijau kuning & 0,839 & 0,965 \\
\hline Kuning & 0,965 & 1,092 \\
\hline Orange & 1,092 & 1,219 \\
\hline Merah & 1,219 & 1,346 \\
\hline
\end{tabular}

\section{SIMPULAN}

Berdasarkan hasil simulasi yang dilakukan terhadap benda uji, didapatkan hasil bahwa untuk deformasi mengalami 9 tahap deformasi sebelum mencapai maksimal sebesar $0,0238 \mathrm{~mm}$ di bagian atas kolom. Pada equivalent stress melewati 4 tahapan sebelum mencapat kondisi akhir dimana ujung bawah berwarna hijau muda dengan tegangan berkisar antara 0,436 Mpa sampai 0,458 Mpa, sedangkan bagian tengah sampai atas berwarna kuning dengan tegangan berkisar antara 0,458 sampai 0,48 . Pada directional deformation, tegangan terbesar terletak di sisi luar dengan besar tegangan berkisar antara 0,502 Mpa sampai 0,523 Mpa. Sedangkan tegangan terkecil berada di tengah penampang yang dengan besar tegangan berkisar antara 0,327 Mpa sampai 0,349 Mpa. Perlu dilakukan penelitian lanjutan untuk beton bertulang sehingga bisa dibandingkan hasilnya dengan hasil simulasi.

\section{DAFTAR PUSTAKA}

ANSYS Inc, 2009, Advanced Analysis technique, 3rd Edition, Southpointe, Cannonsburg

ANSYS Inc, 2009, Commands reference, tenth Edition, Southpointe, Cannonsburg

ANSYS Inc, 2009, 8.0 Manual Set, ANSYS Southpointe, Canonsburg

ANSYS Inc, 2009, Theory Reference, Seventh Edition, Swanson Analysis Systems, Southpointe, Canonsburg
ANSYS Inc, 2009, Engineering Analysis System. Theoritical Manual (for ANSYS revision 8.04), Southpointe, Canonsburg

Bangash, MYH, 1989, Concrete and concrete Structure, Numerical Modelling and Aplication, Elsevier Science Publisher Ltd, London, England.

Job, Thomas, 2002, Non Linier Analysis of Shear Dominant Prestressed Concrete Beam Using ANSYS, Indian Institute of Science, Bangalore, India.

Ruus, K., Handono, B. D., dan Pandaleke, R., 2017, Pengaruh Bentuk Badan Profil Baja Ringan Terhadap Kuat tekan, Jurnal Sipil Statik, Vol 5, No 5, Hal 249-262.

Segui, WT, 2007, Steel Design 4th ed Canada, Chris Carson. 